\title{
Debate: "Historia, antropología y folclore". Reflexiones de los autores y consideraciones finales de la editora
}

Ricardo G. Abduca, Diego Escolar, Andrea Villagrán y Judith Farberman

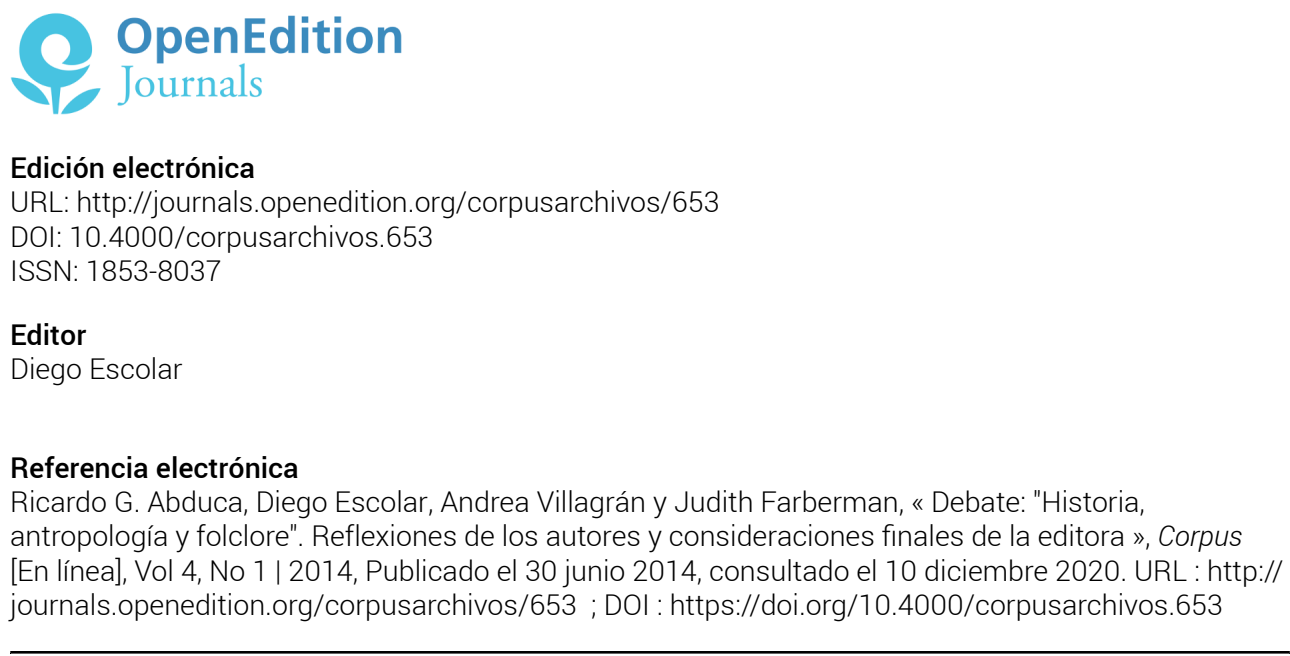

Este documento fue generado automáticamente el 10 diciembre 2020.

Licencia Creative Commons: Atribución-NoComercial 2.5 Argentina (CC BY-NC 2.5 AR) 


\section{Debate: "Historia, antropología y folclore". Reflexiones de los autores y consideraciones finales de la editora}

Ricardo G. Abduca, Diego Escolar, Andrea Villagrán y Judith Farberman

\section{Ricardo Abduca}

1 En la reunión que mantuvimos en septiembre de 2013, y en los textos distribuidos, encuentro primero el interés estimulante de los organizadores y participantes y la riqueza de información, de análisis y matices en los textos de Andrea Villagrán y Diego Escolar. Asimismo, el denominador común de estar marcados, al igual que mi intervención, por la vigencia de los debates en torno a las tradiciones "gauchas" o criollistas. Para decirlo de otro modo, la continuidad y vitalidad de los debates sobre las formas de transculturación de lo autóctono y lo foráneo, lo europeo y lo indígena, que recorren nuestra historia desde aquel núcleo originario y mixto de guaraníes y españoles, establecidos en la cuenca del Paraguay en tiempos de Ayolas e Irala, que luego fundó Buenos Aires.

2 Mi comunicación apuntó a situar al folklore no solo en relación a la "antropología" social o etnología, sino a los estudios lingüísticos -en particular confronto alguna hipótesis salida del diálogo con interlocutores (lo que se puede considerar el núcleo del método etnográfico) con las evidencias de los repertorios léxicos disponibles.

De las intervenciones de los colegas destaco la ajustada definición que propone Escolar: “ tradición, como reproducción estetizada de núcleos originales de cultura, eventualmente capaces de sostener cierto tipo de identidades primordiales de generación en generación". Al respecto, se ubica en una por él llamada "concepción intermedia", entre la del archivo como un lugar físico sostenido institucionalmente y la postura que 
encuentra archivos en toda pauta clasificatoria. El archivo huarpe se constituye como corpus heterogéneo soportado en diferentes materialidades, discursivas o no.

4 Escolar considera que es un componente teleológico el que constituye como tal a todo archivo: la mirada de un sujeto histórico particular. Esta especie de après coup es el que constituye al archivo huarpe. Si esto ocurre con todo archivo, es más visible en el caso del dislocado archivo huarpe, de manera análoga a lo que ocurre con el fenómeno literario: es el lector, y no el autor, quien le da forma definitiva a cada relato, pero este fenómeno es más visible en ciertas narrativas que en otras.

5 Andrea Villagrán nos muestra un proceso distinto, pero comparable, que tiene sugerencias metodológicas que creo bastante productivas. Me refiero a sus análisis de los procesos de folclorización, "folclorización hegemónica", "folclorización subalterna"... Los estudiosos han reflexionado muchas veces sobre el vínculo de mutua interacción entre lo anónimo oral y lo escrito "como un zigzag que en el curso de siglos enlaza dos niveles de cultura; por una parte la de tipo 'folk' y por otra la individual, escrita... de la ciudad" (Cortazar, 1970, p. 21). El proceso que sugiere Villagrán es comparable, pero muchísimo más rico. Si hay tales procesos de folklorización, entonces podríamos reflexionar bastante sobre qué es lo folklorizante y qué lo folklorizado. Cómo sujetos y prácticas que están empezando a ocupar una posición pasiva, porque están siendo impregnados del olor a formol de los museos, pueden sin embargo desperezarse y correrse de esas posiciones.

Otro denominador común que encuentro en el espíritu de las comunicaciones y los comentaristas es aceptar cierta tensión paradojal entre diversos puntos de vista sin pretender resolverla o suprimirla del todo. ¿Es que lo que hacemos es folklore? ¿Es que hay una tradición argentina específica de estudios folklóricos, relacionada con las tradiciones de la gauchesca? Por mi parte, si tuviera que contestar que sí, lo haría de esta manera. Es característico de Argentina y Uruguay la fuerte marca de la literatura gauchesca, de Lussicha Zitarrosa, de Ascasubi hasta Leónidas Lamborghini, y la presencia del lunfardo y cierto criollismo en letras de rock. La tensión entre lo gauchesco o criollista y lo fantástico es constitutiva no solo de la obra de Borges sino de buena parte de la literatura argentina. Así, es posible que esta tensión esté presente en buena parte de la antropología argentina: entre nuestro rol criollista de rescatar (reinscribir) tradiciones últimas, por un lado, y nuestro rol de lenguaraces y readaptadores de las corrientes intelectuales dominantes en el debate contemporáneo en los grandes centros académicos del mundo, en los cuales la Argentina ocupa un lugar evidentemente periférico ${ }^{1}$.

\section{Diego Escolar}

7 La segunda ronda de este debate habilita a algunas reflexiones, en parte directamente relacionadas con los planteos de las tres intervenciones anteriores, en parte tangenciales, en uso de una mayor libertad especulativa, aunque pretendiendo hacerles justicia.

8 Lo primero que cabría destacar de las ponencias de la primera ronda del debate es una coincidencia que puede provocar cierta sorpresa, por la falta de orientación previa. Sin que haya sido propuesto en sus pautas iniciales, las ponencias giraron en torno a la identidad de la figura del gaucho y su carácter de objeto, patrimonio o sujeto. En el caso de Villagrán, la saga narrativa de Güemes, su frondosa derivación ritual y mítica, la dinámica de los fortines gauchos y las disputas de hegemonía en que se inscriben. En el de Abduca, el lenguaje gauchesco y los propios gauchos formoseños como relicto. En el 
propio, los indios/criollos de Cuyo, el archivo huarpe y la propiedad sobre este y la identidad huarpe.

El gaucho rodea este debate no por casualidad. Aunque la disciplina o subcampo del folklore ha roto hace ya mucho tiempo con este estereotipo, sigue siendo para muchos de nosotros su más fuerte referente histórico y en gran medida su creación, o al menos el núcleo de un debate sobre las relaciones entre disciplinas. En primer término, el gaucho, real o imaginario, fue uno de los mojones sobre el que se dividió el campo de la antropología. Los folkloristas, como Rojas, Carrizo, y los artistas del folklore en tanto movimiento estético a lo largo del siglo $\mathrm{XX}$, tendieron a representar como "criollos puros" - esto es con preponderancia de cultura hispana- a poblaciones que en algunos casos practicaban las más visibles tradiciones indígenas, hablaban lenguas originarias y en muchos casos (como los Valles Calchaquíes, Santiago del Estero o las travesías y valles cuyanos) mantenían en buena medida una ocupación territorial o memorias y culturas políticas que se remontaban a experiencias indígenas de la época colonial. En contraposición a ello, subdisciplinas como la arqueología, la etnología, la etnografía y en general antropólogos enrolados en la escuela histórico-cultural, se enfocaron sobre poblaciones nominadas como "indígenas". Mientras, la más joven antropología social siguió en un principio el camino del folklore (en cuanto al estudio de poblaciones "no indígenas"), pero abriendo más decididamente el camino a tomar como objeto otras identificaciones o representaciones de grupos sociales, ni indias ni gauchas, sino campesinos, "cabecitas negras" o "sectores populares".

10 La historiografía por su parte fue bastante reticente a considerar la posibilidad de que los indios fueran sujetos históricos de una historia "nacional", hecho que sólo comenzó a revertirse en las últimas dos o tres décadas. Estudiar la historia de los indígenas le había correspondido fundamentalmente a la etnohistoria, o a los historiadores coloniales que tangencialmente la abarcaban. Y ello porque el abordaje histórico de las poblaciones indígenas en este escenario, adoptando el paradigma criollista asociado con la formación del Estado nación argentino, se proyectaba siempre sobre períodos anteriores a los procesos independentistas.

11 Es este el legado que aún pesa, no solo sobre los debates y prácticas disciplinares, sino sobre las propias imaginaciones históricas y antropológicas.

12 Por eso una de las partes más interesantes del texto de Ricardo Abduca es cuando narra su encuentro con gauchos en Ramón Lista, en el oeste de Formosa. "Adquirí la convicción que estos criollos del Chaco eran los últimos gauchos. Ignorados, hasta donde sé, por la gran cantidad de estudios de etnografía chaqueña, volcados al mundo indígena".

13 Abduca expresa, con intencional desconcierto, que en un lugar donde los antropólogos solo estudian indios, él encontró los "últimos gauchos". Los gauchos de Formosa, señala, han mantenido más continuidad cultural con los gauchos del siglo XIX que los indios del Chaco en general con los de períodos anteriores. Esta continuidad estaría caracterizada por la presencia de ciertos elementos de cultura material como lazos, boleadoras y guardamontes, o actividades como las carreras cuadreras, todos ellos asociados a la práctica de la ganadería a campo abierto. Es posible que esto sea rigurosamente cierto. Sin embargo, me interesa señalar el papel que juegan estos sujetos, o más bien las identidades que les conferimos, en nuestros propios discursos identitarios y legitimación disciplinar. 

criollos o gauchos en los estudios antropológicos de la región chaqueña es radical en efecto con relación a cierto tabú antropológico sobre la población criolla local. Este tabú no solo depende de la geografía sagrada de los linajes académicos (líneas de profesores y alumnos que tendieron a desplegarse a través del tiempo en las mismas áreas o en torno a temas y poblaciones afines), sino también de perspectivas teóricas e ideológicas que es posible historiar.

15 Entre las primeras, podría señalarse la tendencia a clasificar -y buscar o construirgrupos "étnicos" nítidos, que a su manera propiciaron tanto las raíces históricoculturales, estructuralistas, en menor medida (por su escasa influencia) las culturalistas, y, a su modo, también las aproximaciones marxistas, de la antropología chaqueña. Para las primeras tres, el estudio de la "cultura" indígena era un objeto mucho más interesante que los criollos, cuando no el objeto de una misión de rescate, toda vez que el cambio cultural y social era considerado una amenaza para la existencia misma de estos grupos, o sea para la existencia misma de los objetos etnográficos y por ende de la propia antropología. La división, primero, entre indios (o aborígenes como es más común escuchar en el Chaco) y criollos, es vista como radical y evidente, y lo es seguramente en varios términos. Tal cual comentaba un colega experto en etnografía chaqueña hace diez años, Gastón Gordillo, las identidades étnicas como tales, sus transformaciones, "emergencia" o "construcción" ni siquiera eran consideradas temas de investigación ya que su existencia se daba por sentada, constituyendo un dato casi natural del mapa social. Para los antropólogos de raíz marxista o subalternista (más comprometidos con las luchas por los derechos y supervivencia física de los indígenas), los aborígenes en tanto víctimas de discriminación racial y étnica generan una empatía que no es automática con los criollos, que ocupan y ocuparon históricamente el lugar de victimarios y con los cuales mantienen violentos conflictos sociales. Por ello, es claro que los indios son el objeto "natural" de un antropólogo en el Chaco, y Abduca da en la tecla al llamar la atención sobre esta brecha, que es efecto de la propia tradición antropológica. tradicional de la antropología: el deseo salvífico de restituir el instante extinción, del cual el antropólogo se presenta como único testigo. En este sentido, esta figura viene a ocupar el lugar de la más típicamente antropológica del "último indio", a punto siempre de desaparecer pero que siempre permanece, movilizando la labor etnográfica desde fines del siglo XIX. En términos comparables a este folklore científico, el gaucho es presentado además como digno de atención, particularmente por la supervivencia de su cultura, mantenida más intacta que la de los indios respecto del tiempo mítico del gaucho: el siglo XIX. Pero este gaucho del XIX que se toma como referencia es también el del folklore clásico de Carrizo, el del complejo ecuestre y las cuadreras, pero no el que eventualmente ve televisión, manda a sus hijos a la escuela o participa de un "fortín gaucho" como analiza Andrea Villagrán en su texto. De algún modo, esta visión "continuista" del gaucho podría implicar una perspectiva inversa a la que, cada uno a su modo, historiadores como Gelman, Fradkin, De la Fuente y otros vienen propiciando hace años: des-fetichizar al gaucho mostrando la complejidad y variedad de relaciones sociales, prácticas económicas y políticas que rompen el estereotipo construido en torno a él (por ej. el gaucho labrador o jornalero, con su parcela, en lugar del nómade cazador de ganado; el gaucho político, en lugar del 
cuerpo bruto de los ejércitos; el gaucho con su "esfera pública" de los pobres en lugar del iletrado carente de opinión).

El análisis de Abduca, que con su sutileza permite al menos dos lecturas (la descripción de un paradigma culturalista o estructuralista o la crítica a estos y, por extensión, al núcleo tradicional de la etnografía chaqueña) pone en evidencia que frente a la visibilización del indio, o el aborigen, el gaucho chaqueño puede ocupar hoy el lugar que el indio ocupaba en la antropología clásica: resabio condenado a la desaparición, pero que por eso mismo moviliza el ethos disciplinar, se carga de valor hasta convertirse en un fetiche y fuente manática del conocimiento etnográfico. El gaucho en Formosa, en tanto resto excluido e invisibilizado, hoy podría ser para la antropología "más indio" que el indio.

difícil evitar sin embargo pensar que hay algo en el contexto político actual que provoca la idea de la "modernidad" o inautenticidad etnográfica del indio con respecto a la tradicionalidad y autenticidad del gaucho. El oscurecimiento del criollo chaqueño es estridente precisamente porque el indio chaqueño está en un momento de fuerte visibilización. Las provincias de Formosa y en menor medida Chaco se convirtieron en foco de atención por reiteradas denuncias de violaciones a los derechos humanos de indígenas, que si bien no son nuevas, adquirieron una trascendencia pública creciente (entre otras cosas por el modo en que son deslegitimadas por un gobierno que basa parte sustancial de su identidad en una política que se postula defensora irrestricta de los derechos humanos). La movilización política de los indígenas chaqueños, concitando o buscando la atención de los medios, difundiendo como nunca antes sus conflictos y la violencia de que son objeto, obteniendo el apoyo o el denuesto de figuras públicas, ha generado acusaciones de "mostrarse demasiado". Es decir, la revisibilización del indígena chaqueño parece darse no tanto como "indio hiperreal", en el sentido de Alcida Ramos (sobre la base por ejemplo de la actuación de un indio folklórico, más afín al paradigma etnológico), sino cada vez más como el escandaloso "indio político", en el sentido de Axel Lazzari, que no actúa como la sociedad esperaría de un indio, sino como "nosotros".

Estas reflexiones permiten avanzar un poco más en el tema planteado al comienzo de este ensayo, el eje crítico o "gran división" indio/gaucho en el trabajo disciplinar y subdisciplinar.

Ciertamente, sea el mote utilizado por Abduca una interpretación literal o un juego retórico, los criollos del Chaco no son los "últimos gauchos". El trabajo presentado por Andrea Villagrán de cuenta de la centralidad, más allá de los criterios de autenticidad con que se los pueda evaluar, de una proliferación social de figuras y prácticas gauchescas en la carrera güemesiana de los salteños. Lo gaucho ingresa allí, al contrario que en Formosa, como un capital en disputa por patrones, peones, gauchos sin tierra e intelectuales. Para caracterízar al gaucho, Villagrán describe actividades similares a las que señala Abduca y otras adicionales:

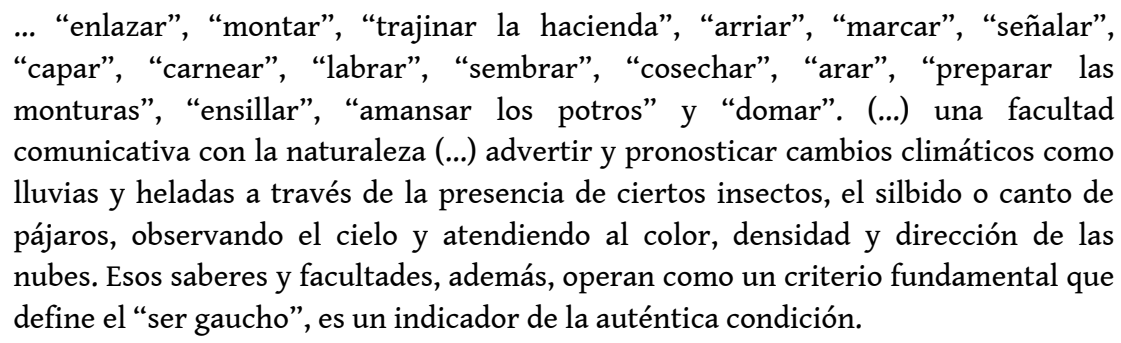
querer abundar, es posible observar por ejemplo algunas prácticas y objetos análogos en 
uso entre los campesinos o "puesteros" de las travesías y montañas cuyanas. La ganadería de "campos abiertos", que incluye ganado semicimarrón y formas de manejo de animales silvestres como el guanaco; el uso de lazos y diversas tipos de boleadoras: las de caucho para atrapar potros o guanacos, de piedra para choique (o churi, o avestruz) según la localidad y también guanaco, de tuercas o plomo, de dos masas, con cuerda de alambre para aves o para arriar cabras, o "bolas guachas" (boleadoras de una sola piedra o masa, llamada antiguamente "bola perdida") para matar pumas (en las Lagunas de Guanacache todas ellas con su "colorado", trozo de tela para encontrar la boleadora que, arrojada, no hizo blanco); guardamontes, cuadreras, pialadas, campeadas, malambos y cuecas, geopolíticas de cuatrerismo recíproco, etc. También, como señala Villagrán, la "facultad comunicativa con la naturaleza".

Imagen $\mathrm{N}^{\circ} 1$ Boleadoras de alambre con "colorado". Foto de Diego Escolar

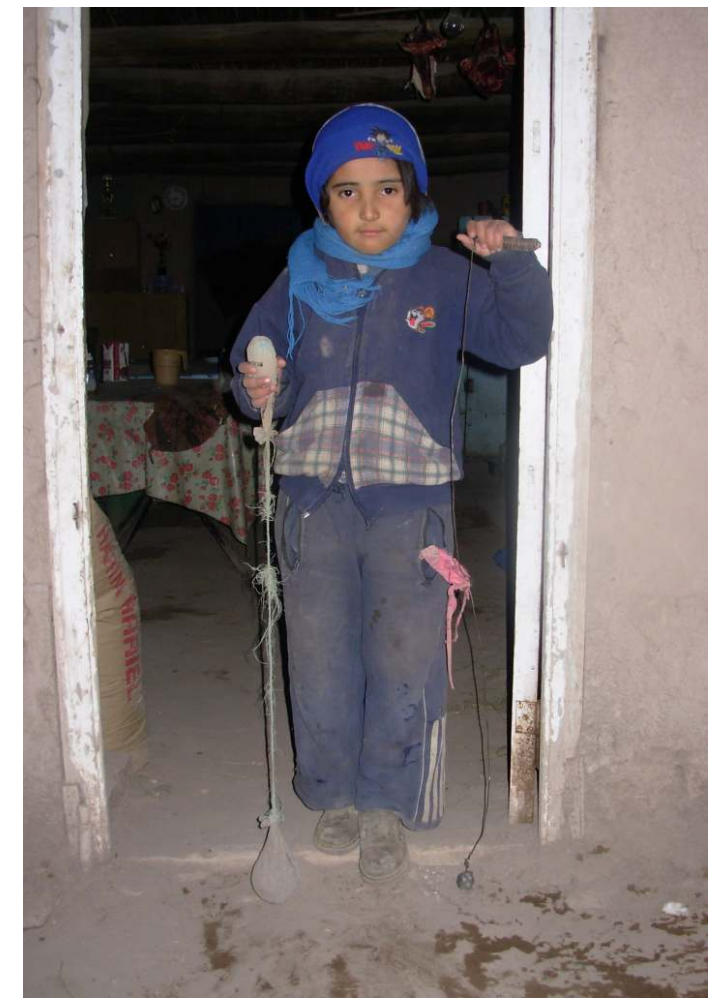

Pero veamos el nudo de esta argumentación, la distinción criollo-indígena. Sin perjuicio de que en el Chaco y otras regiones constituya uno de los principales clivajes de división social, es erróneo pensar que tal distinción es generalizada y, sobre todo socialmente, operativa en toda la Argentina. Los actuales pobladores de Guanacache, retomando un ejemplo tal vez extremo, no consideran que ser criollo o gaucho se oponga a identificarse como huarpes o descendientes de tales. Como ha señalado Alejandro Isla para Amaicha en Tucumán, personas que pueden identificarse como indígenas y rememorar eventos de una historia indígena, e incluso eventualmente movilizarse como tales, también pertenecen a los "fortines" o participan de procesiones gauchas. En suma, lo que los laguneros de Guanacache apuntan como tradiciones huarpes suelen coincidir con lo que en Formosa hacen los gauchos o criollos, más que con los modos de vida de los qom o los wichi de la región chaqueña. 

caudillos, degüellos, levas y arreos. En sus memorias, una de las marcas de indianidad de los viejos "indios" de la década de 1920 es que usaban chiripá y botas de potro, el mismo atuendo típico de los gauchos; el principal héroe local, el caudillo decimonónico Santos Guayama, es considerado generalmente (al igual que los más ricos ancianos cabezas de familia de las primeras décadas del siglo XX) como cacique o incluso cacique huarpe, y se lo venera aún semisecretamente en una figura de santo vestido de gaucho. Estos gauchos indios, o indios criollos, obtuvieron recientemente parte de sus tierras en título comunitario indígena en gran medida sobre la base de investigaciones y reconstrucciones de demandas de tierras que sus jueces o comisarios sostuvieron a lo largo del siglo XIX y principios del XX, en tanto "indios laguneros" reducidos en el siglo XVIII, y que distintas familias habían atesorado, copiado a mano y escondido durante todo ese período.

Para la mayoría de los observadores locales y los historiadores y antropólogos, sin embargo, la sola posibilidad de pensar indigenidades contemporáneas en Cuyo era considerada un sinsentido. En cambio, hablar de gauchos en Salta toca directamente un tema-monumento nacional que todo argentino puede identificar inmediatamente como veraz.

Los gauchos salteños son un patrimonio nacional y la gauchesca fortinera de la salteñidad una producción hegemónica pujante. Villagrán describe la construcción mítica de que es objeto la figura de Güemes, aceptándola como "despolitizante". Hacia el final de su texto, introduce el concepto de hegemonía que estaba notoriamente ausente en las primeras presentaciones del debate. Con resonancias del Gramsci de Lombardi-Satriani, alude a dos movimientos en la lucha cultural por la figura de Güemes y los gauchos salteños: una "folclorización hegemónica" que "a través de los procedimientos de heroización y mitologización, de actualización ritual y espectacularización" transforma la historia real (de Güemes, de los gauchos) en ornamento, y una "folclorización subalterna", opuesta, cuya característica central sería que restituye una función práctica y cotidiana a la tradición y un vínculo entre presente y pasado, que reconvierte a los gauchos concretos en actores sociales particulares, en campesinos en lugar de símbolos.

Creo sin embargo que, contra lo que la deriva de un racionalismo sociológico o un materialismo mecanicista podría inducir a pensar, el mito no es necesariamente opuesto a la realidad, ni mucho menos despolitizante. Independientemente de la orientación valorativa o el contenido, los mitos o las mitologizaciones son una de las materias primas y procesos centrales de la política, más aún si la entendemos como producción de hegemonía. La maquinaria formalista de la producción (y disputa) de hegemonía en el sentido de Laclau, requiere, como sabemos, un trabajo simbólico para generar cadenas de equivalencias entre particulares antagónicos que permitan un grado de universalización suficiente para articularlos en un proyecto común mediante la identificación con un "significante vacío". Los subalternos no pueden revertir su condición de subalternidad en la carencia de símbolos y mitos por los cuales puedan articular formas de subjetividad colectiva que les permita generar demandas o movilización, y este es el trasfondo de la conocida discusión de Spivak sobre la posibilidad o no de una "voz" subalterna. El subalterno, para ser escuchado, debe formular un discurso como mínimo inteligible en el escenario político (hegemónico), pero al momento de lograrlo ya está de algún modo revirtiendo su condición de subalternidad, esto es comenzando a ser un sujeto (desde esta perspectiva sería en esencia un contrasentido postular, como habitualmente se hace, la existencia de "sujetos subalternos"). 
El problema real de la política, entendida como producción y disputa de hegemonía, y el análisis de la hegemonía, es la atribución de un contenido y más aún de una moral a esta última. En algunas lecturas anarco-liberales que la corriente de los estudios culturales tendió a sesgar sobre postulados de Gramsci y Lenin, se le ha atribuido a la hegemonía un carácter negativo, sentido que está asociado en la práctica, independientemente de la complejidad de algunos análisis, al concepto de simple dominación estatal o de clase. Son innumerables los estudios históricos o antropológicos, tanto en la Argentina como en el exterior, que utilizan términos como "hegemonía del Estado nación" o "hegemonía del Estado", para denotar en rigor los aparatos ideológicos y culturales de control estatal o burgués, cuando en realidad la hegemonía para Gramsci o Lenin era básicamente una estrategia política para que clases subalternas pudieran tomar el control sobre el Estado. En el análisis de Laclau se recupera esta visión, pero también por momentos con deslices "contenidistas", adjudicándole al proceso de construcción de hegemonía una teleología emancipatoria que entra en contradicción con sus postulados sobre las características formales de la hegemonía como procesos de articulación que, si los seguimos al pie de la letra, no ofrecen evidencias sobre el contenido de los símbolos y proyectos que se impondrán, ni cuáles serán los puntos de articulación ni el resultado del proceso histórico.

Esto permite admitir que, desde una perspectiva materialista, podría afirmarse paradójicamente que los mitos o folclorizaciones no son necesariamente despolitizadores ni un atributo de la dominación de clase o estatal, sino en todo caso una condición de la política, y más estrictamente de la representación e imaginación políticas. En todo caso, lo que los gauchos pobres y "auténticos" de Salta estarían disputando es la apropiación de sus prácticas y símbolos para la legitimación de una clase o bloque antagónico dominante, a través de una determinada folklorización de la historia. El folklore como patrimonio de un Estado o "comunidad imaginada" provincial que, articulado con la legitimación del poder de ciertos grupos, aliena los significados y símbolos que pretenden mantener o reorientar los gauchos. 
Imagen $\mathrm{N}^{\circ} 2$ : Boleadoras de rodajas de cubierta de auto y de piedra con cuerdas de nylon. Foto de Diego Escolar

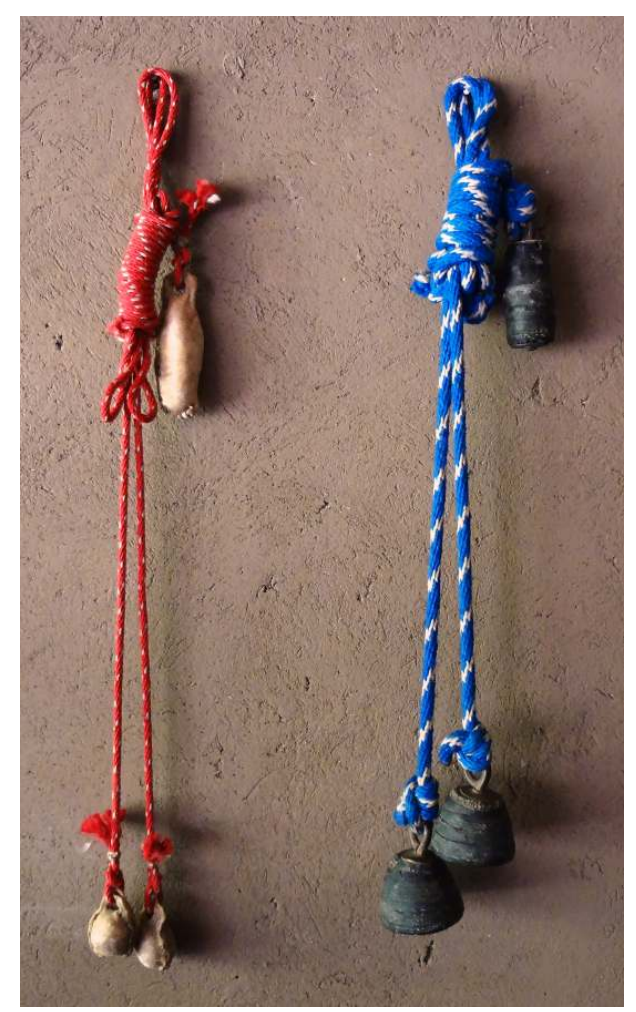

Estos mismos subalternos, sin embargo, pueden procurar o encontrar en determinadas condiciones las formas de producir sus propios mitos o narrativas, apropiándose inclusive de significados hegemónicos, o al menos integrándolos en un régimen de inteligibilidad que les permita una eficacia política, o la posibilidad misma de articularse como sujetos políticos. Retomando el caso analizado, pobladores de áreas rurales de Cuyo, como Guanacache, en conflictiva relación con intelectuales, políticos profesionales, curas, maestros, abogados e intelectuales, han venido produciendo, rescatando y reciclando mitologizaciones huarpes, basadas en el "archivo huarpe" analizado en la primera intervención del debate. Este proceso es generado por múltiples factores, y no es un mero efecto del archivo, pero tampoco una invención soberana (es decir, ni controlado eminentemente por las "comunidades huarpes" ni objeto de una absoluta imposición de un libreto de multiculturalismo neoliberal). Pero no habría sido viable sin la existencia de memorias e historias indígenas (o de lecturas indigenizadas de su historia y memorias) basadas en prácticas archivísticas e historiográficas realizadas por sus ancestros, la histórica movilización de estos mismos para defender territorios, acceso a recursos, controlar la "propiedad" de sus propios cuerpos, o lograr una incorporación política estatal. Pero fundamentalmente, no sería viable sin los "mitos" de los caciques y caudillos huarpes, como Santos Guayama y Martina Chapanay, de las salamancas indígenas, de los sueños con mandatos ancestrales y de la cultura indio-gaucha. Que el resultado de este proceso sea una utopía de emancipación social o un ciclo de mayor alienación política sobre esas poblaciones, es otro tema. 


\section{Andrea Villagrán}

30

El señalamiento sobre la "naturaleza impura" de las cosas folklóricas parte de la sospecha que permite problematizar "lo folklórico", adscribirlo en un proceso de devenir. Es decir, centrar la cuestión en el modo, los procedimientos y las operaciones a través de las cuales ciertas "piezas", objetos, textos, canciones, expresiones, se hacen merecedores y depositarios de tal atributo o cualidad y adquieren el estatuto de "objetos folklóricos". Ricardo Abduca, por su parte, entiende por folklore al "proceso de inscripción" de las prácticas populares en un corpus académico. En su planteo, la atención y el interés se concentran en la cualidad de registro de esos escritos, en la información que ofrecen y las interpretaciones que se habilitan desde los estudios de carácter etnológico o historiográfico.

Avanzando un poco más en la reflexión, me interesa resaltar el carácter discursivo de esos "materiales", focalizando en las diversas posibilidades, contextos y situaciones de uso, relectura y apropiación como instancias constitutivas de lo "folklórico" como tal.

Particularmente, en las investigaciones que realicé y a las que aquí me remito, propuse desentrañar los mecanismos a través de los cuales se producen y reproducen ciertos sentidos y nociones relativas a la "identidad provincial" en Salta, en donde claramente un tipo de producción histórica y literaria -susceptibles de clasificarse como materiales folklóricos- resultaban claves para comprender el anclaje de esquemas de percepción y significación en "lo gaucho", "el pasado" y "la tradición" y su articulación en una noción singular de "salteñidad". En función de ello, advertí la utilidad y necesidad de abarcar la heterogeneidad de situaciones y formas de producción de "lo folklórico". Considerando que los discursos folklóricos requieren ser explorados a través de las relaciones que se entablan entre presente y pasado, en tanto cuerpo de ideas, conceptos, imágenes que permiten conocer, clasificar, ordenar e interpretar, como constructores de esquemas de visión y valoración, pero cuyo potencial no se agota en la producción de efectos de sentido a partir de enunciados, sino que se despliega en la pluralidad de situaciones prácticas y formas de uso, donde los elementos constitutivos de esos discursos se articulan y re-integran conformando otros discursos, generando acciones, orientando prácticas, configurando imágenes, en esa dirección veo la importancia y ventaja de razonar en clave de proceso de folklorización (folklorización, des-folklorización y refolklorización), que brinda la suficiente apertura y flexibilidad para contener el complejo y múltiple encadenamiento de instancias y etapas que lo dinamizan (producción, circulación, re-significación y re-articulación). En ese entramado de "redes intertextuales" y "socio-materiales", se rozan personas y cosas, como sugerentemente propone D. Escolar.

Lo antes dicho enfatiza entonces las dimensiones de complejidad y multiplicidad involucradas y, agregaría a ello, relacionalidad. Atender al modo como opera, al uso y construcción de "lo folklórico", conduce al eje de las relaciones de poder, sus técnicas, estrategias, a las posiciones y relaciones entre actores y grupos, y a la imbricación de la folklorización con los complejos engranajes y mecanismos de articulación entre "lo hegemónico" y "lo subalterno" con las formas y los medios de producción y reproducción de la desigualdad, y también con las tácticas y luchas que descompensan un estado de distribución de fuerzas y recursos, aspirando a subvertirlo. 

pasado" desde los grupos de peones y ex-peones rurales, desde los "gauchos sin tierra", se revelan las tensiones, contrastes y solapamientos, la implicación recíproca entre folklorizaciones hegemónicas y subalternas.

sentido, la recuperación de tempranos intentos de re-enfocar desde un análisis crítico la cuestión del folklore aportaría a complejizar el tratamiento. Kate Crehan (2004) es una de las figuras más visible de una corriente de re-lectura y recuperación del pensamiento de Gramsci, que le otorga un lugar de importancia en el desarrollo de las teorías antropológicas, desde la asociación entre los conceptos de cultura y hegemonía. Esta línea discute con las interpretaciones más difundidas, las cuales reducirían los planteos a una simplificada polarización. Crehan relee los Cuadernos de la cárcel y desde la dispersión de esos escritos compone una fórmula para desfolklorizar. Retoma la crítica de Gramsci, que cuestiona el tratamiento del "folklore" como un "elemento pintoresco". Identifica allí indicaciones para encararlo desde lo contradictorio, fragmentario, singular y atendiendo a la historicidad. Más que asignarle un lugar fijo y definido -aunque lo identifica con los grupos subalternos-, este autor ubica al "folklore" en un cruce, a través de vinculaciones; "en relación con la cultura de la clase dominante y las partes cultas de la sociedad" y en oposición a las "concepciones oficiales del mundo".

Respecto al cruce antropología-historia-folklore, agrego algunas líneas centrándome en algo que gravita alrededor de los textos sin la suficiente explicitación en las distintas concepciones sobre el quehacer antropológico. clasificaciones habituales, que separan las disciplinas en compartimentos estancos, en una suerte de reparto de campos de saber y en función a formas de ver y hacer normalizadas.

El tratamiento de "lo histórico" y la relación con la historia atraviesan las discusiones y desarrollo teóricos en la antropología desde mediados del siglo XX. Un hito en ese sentido es la polémica que instala E. Pritchard hacia los años sesenta, donde cuestiona los enfoques antropológicos ahistóricos y antihistóricos, definiendo a la antropología como una disciplina histórica.

39 En las últimas décadas adquirieron notable presencia en las discusiones epistemológicas, y políticas, las propuestas que aspiran a superar la parcialización del conocimiento en las ciencias sociales. En un orden de radicalidad ascendente estas van desde la interdisciplina y trans-disciplina hacia la in-disciplina. Postulan, de un modo $u$ otro, traspasar y/o desdibujar las fronteras disciplinares ponderando la expansión del horizonte de visión, aprehensión y comprensión de los fenómenos sociales.

Estas líneas introducen los comentarios en torno a las investigaciones y "objetos" ubicados en zonas de frontera, contacto y contaminación, si se permite la expresión, para resonar en la clave de la impureza. Desde esa lógica, es de suponer que en la situación de frontera suceda la migración y el tráfico, tanto a nivel teórico como metodológico, y que ello apareje cambios y replanteamientos en el interior de la disciplina que opera como receptora, y hasta tal vez impulse el surgimiento de áreas o campos de especialización. Ello lleva a suponer que si bien sería posible identificar y asumir ciertos límites para diferenciar un "campo" de otro, hacia adentro cada uno de estos se conforma heterogéneamente. Desde esta advertencia, se puede reconocer la presencia de distintas 
antropologías, vinculadas a específicas "tradiciones", linajes teóricos, preocupaciones, modos de abordaje y recortes temáticos.

Entonces, más que en la antropología pienso en la coexistencia de modos de antropologizar, de construir y plantear problemas y formular preguntas, que se definen por el tipo de uso y combinación de las técnicas, instrumentos y herramientas que la disciplina ofrece. Para lo que estudio, encuentro referencias en el quehacer donde predomina la perspectiva etnográfica (como modo de ver, interrogar y analizar). En este, los instrumentos (técnicas y recursos) y herramientas (conceptos) se calibran y ajustan en función del "objeto", así como el diseño de estrategias y procedimientos. El punto de partida es el proceso de prefiguración conceptual de esa mirada, su predisposición y sensibilización para aprehender "objetos" de diversa "naturaleza". Perspectiva analítica que, por tanto, puede ejercitarse y ponerse en juego más allá de lo inmediatamente "observable". Su horizonte de aplicación contempla múltiples situaciones y fenómenos, así como al tratamiento de materiales y registros heterogéneos: acciones, relatos, narrativas, textos, imágenes, todo aquello que tenga una marca de sentido, podríamos decir.

Este enfoque suele apuntalar el desarrollo de trabajos cuyas inquietudes e interrogantes conducen por un derrotero que no se ajusta al repertorio más o menos habitual de procedimientos del "método etnográfico" en sentido estricto. Y, más aún, cuando media un interés por "objetos" que escapan al "presente etnográfico", que involucran "lo histórico", "el pasado" y la relación entre estos y el presente. Cuando el cuestionamiento acerca de la "naturaleza" de las cosas lleva a explorar el modo en que llegaron a configurarse en lo que son, el esfuerzo se encauza a la reconstrucción de devenires.

Imagen $\mathrm{N}^{\circ}$ 3: Trabajos ganaderos en una campeada. Foto de Diego Escolar

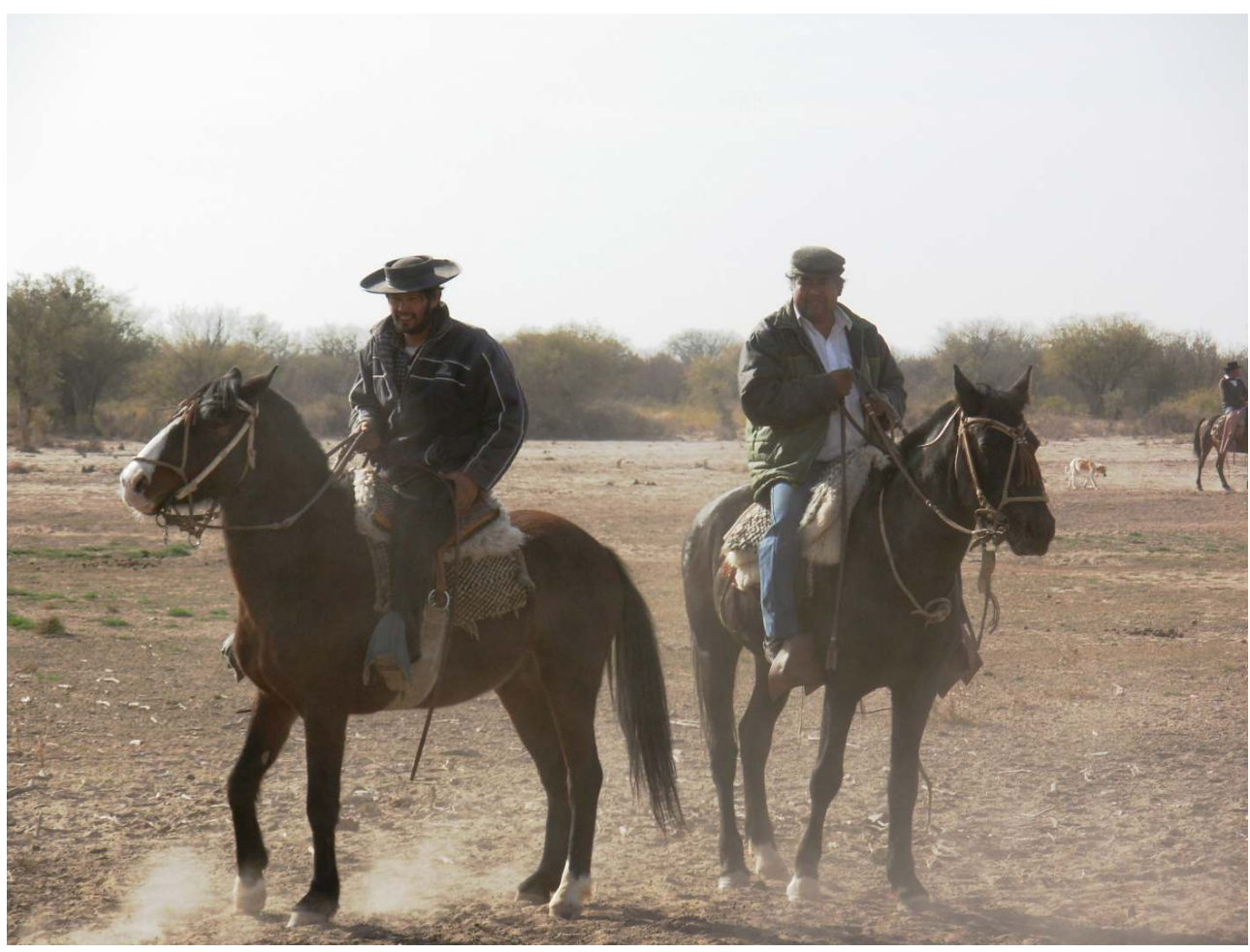

Estamos hablando de una perspectiva que opera a partir del gesto de interrogación continua, y en la búsqueda de respuestas multiplica y diversifica los registros empleados, 
las fuentes a las que recurre. El interés por las características de "las cosas" lleva a la descripción como medio, atendiendo al detalle, a las cualidades, atributos, propiedades, a los rasgos definitorios, realizando operaciones de asociación, comparación, identificación de regularidades, las cuales implican movimiento, ejercitar el cambio de ángulo y punto de vista, hacer foco, seleccionar, acercar y alejar, construir escalas, magnitudes, atender a la profundidad y proporción. Así se descubre lo relativo y particular.

Pero claramente no se trata de una mirada "desnuda", ni pura, se construye teóricamente, se adiestra, ejercita, especializa y agudiza en dirección a dar cuenta de la profundidad, densidad y complejidad de los fenómenos a los que se aproxima. Por tanto nunca opera sola, recurre a los otros sentidos, se firma en ellos. Para observar, escucha (eso que se denomina escucha etnográfica), y para poder ver, también imagina, viaja en el tiempo.

De este modo, el ver se afirma en la experiencia, construye conocimiento combinando información de distinto origen. Los principales “datos", la información primaria, provienen del mundo sensible, de las impresiones y sensaciones. Las anécdotas, sorpresas, accidentes e incidentes, constituyen una reserva, un plus de recursos para encontrar y atribuir sentidos, comprender y explicar. Por ello, esa mirada necesita volver sobre sí misma, cuestionar sus certezas, repasar las vivencias, ordenarlas y organizarlas, extrañarse, analizar, obrar reflexivamente.

Se mencionó en las distintas intervenciones el trabajo de campo como momento crucial de la investigación, como esa instancia en donde "lo etnográfico" despliega su potencialidad. En su artículo, R. Abduca se refirió a ello a partir de la revisión de una "anécdota" que deviene "incidente". Sostuvo: "puedo aportar una explicación más satisfactoria (...) y puedo hacerlo gracias a experiencias de campo". Sugiere un haz de sentidos sobre los términos "prenda" y "pilcha" de mayor amplitud que el que ofrece la literatura especializada, el género gauchesco y los diccionarios.

En la línea de esa afirmación, la experiencia y registro de campo otorgarían la clave de decodificación, obrarían como un medio para expandir las posibilidades interpretativas. Funcionando como un registro madre a través del cual leer los otros registros y validar o refutar la información por ellos proporcionada. En la operación de confrontación efectuada se revela la deficiencia del corpus textual folklórico, las limitaciones de la información que ofrece, del espectro de sentidos que cubre y tal vez las fallas y restricciones del proceso mismo de inscripción-traducción de lo popular al mundo letrado.

Pero la posibilidad de generalizar el uso de este procedimiento y de emplearlo como modelo presenta algunas dificultades y riesgos. Tomo este ejemplo como enseñanza que indica lo poco productivo que resultaría extender esta operación de confrontación cuando se persiguen otros propósitos y fines, cuando se construyen "problemas" y formulan preguntas diferentes.

Relaciono ese procedimiento con el derrotero de mi propia experiencia y encuentro que la interrelación de registros, el atender y explorar cada uno en su singularidad, lejos de permitir desestimar o impugnar la información de uno frente a otro, o de habilitar alguno el acceso a sentidos más auténticos o verdaderos, abrió la posibilidad de adentrar en la densidad, de tener noción de la complejidad, de la multiplicidad, de la articulación y entretejido de nociones, categorías y sentidos. "Lo gaucho", entendido y definido desde "los gauchos" de los fortines de gauchos, desentrañaba un tipo de gaucheidad, 
comparable pero in-confrontable con "el gaucho" construido a través de la literatura de J.C Dávalos. Así como el Güemes de las narrativas históricas de B. Frías no podía ser reemplazado por los Güemes de la ceremonia conmemorativa del 17 de junio, la situación ritual ponía en escena la multiplicidad de Güemes posibles y existentes, los integraba y mostraba la tensión y superposición entre ellos. Y en ese sentido, "las tradiciones gauchas" de los gauchos de fortines, con quienes trabajé, no se refieren ni a las pilchas, ni a las prendas, ni a los maruchos, tal vez posiblemente a una que otra boleadora, pero ello cuando desde sus relatos se refieren a las aventuras de "antes", cuando podían andar por los montes, "antes" de que cambiaran las posibilidades de acceder a la tierra y los expulsaran de las fincas.

Esta observación repara en los límites y efectos de un alineamiento de procedimientos, sobre la pertinencia y, en última instancia, sobre la utilidad del diseño de estrategias ad hoc. Diego Escolar define como "errática aproximación" a su forma de acercamiento e ingreso al universo de materiales que conforman el "archivo huarpe". Coloca así a la investigación antropológica próxima a un proceso de búsqueda-interrogación, que avanza a través de la experimentación e improvisación, mediante el desarrollo de estrategias particulares más que en ajuste al cumplimiento de pautas de rigor y códigos de procedimientos generales.

51 Vista así, la investigación adquiere un carácter que la acerca al trabajo artesanal, de oficio, que involucra lo sensible, la combinación entre técnica y creatividad. Lo que resulta de su proceso puede tomarse como producto-creación, cuya calidad y originalidad descansa en el adecuado uso de las herramientas, la adaptación, ajuste y precisión de los instrumentos, depende de la habilidad y destreza en el manejo de la técnica, del conocimiento que se apoya en la práctica y la experiencia.

\section{Judith Farberman}

52 Los trabajos aquí reunidos han superado con mucho las expectativas iniciales de este encuentro, aunque focalicen casi exclusivamente sobre dos cuestiones: la de los corpus folclóricos - en particular aquellos levantados ya hace muchos años por los pioneros de la disciplina- y la de los procesos de folclorización aún en vigencia. En rigor, si algo queda claro de estas intervenciones es que el diálogo de antropólogos e historiadores con la producción y las problemáticas del folclore actual es hoy prácticamente nulo.

53 No siempre existió esta distancia. Folclore e historia, folclore y antropología caminaron de la mano durante mucho tiempo, a veces practicados por los mismos profesionales o investigadores amateurs. ¿No se desempeñaban en las tres disciplinas al mismo tiempo Adán Quiroga, Orestes Di Lullo, Canal Feijóo y Juan Alfonso Carrizo? Sin embargo, y ahora hablo sobre todo por los historiadores, pasada la confluencia inicial, hoy desconocemos la producción académica reciente del folclore. Me pregunto si hoy en día su especificidad como disciplina es tan clara como antaño (el relato de Abduca sobre el peso declinante del folclore en el plan de estudios de la carrera de Antropología daría a pensar que no) y si su campo tradicional no ha sido reconfigurado por las nuevas tendencias de antropología social, reorientando los enfoques, las prácticas y las problemáticas. 


\section{El corpus folclórico}

54 Todos los intervinientes en este debate hemos trabajado con materiales producidos por folcloristas e historiadores "tradicionales", preocupados por acopiar "tradiciones populares". En algún caso, el corpus es simplemente lo recogido; en otro también entran a jugar las interpretaciones de los investigadores que en su momento lo reunieron. Notemos que, atendiendo a las citas de los trabajos de nuestros invitados, los textos que mayoritariamente conforman estos corpus pueden datarse entre 1910 y 1950, o sea que surgieron en contextos históricos y al calor de paradigmas científicos muy diversos de los actuales.

El libro reciente de Oscar Chamosa (2012) resume muy bien el clima intelectual en el que se escribieron algunas de las monumentales obras que conforman nuestros corpus como la Encuesta Nacional de Folclore de 1921, los Cancioneros de Carrizo, los Cuentos y relatos del norte argentino y otros textos de Dávalos, o El folclore de Santiago del Estero de Orestes Di Lullo, por mencionar algunas de las que mejor conozco (y me estoy limitando a los textos). Corpus heterogéneo, capaz de albergar desde leyendas, coplas y refranes hasta relatos históricos, pasando por descripciones de rituales agrarios, prácticas de curanderismo y brujería aunque, de alguna manera, también la Historia de Salta de Bernardo Frías y las Tradiciones que comenta Villagrán puedan tener un papel análogo, además de responder su escritura a similares exigencias.

Creo que, si seguimos utilizando estos escritos, no es tan solo por el contenido concreto de lo recogido o porque suma a otras fuentes disponibles, sino también porque compartimos con aquellos folcloristas/historiadores de antaño un terreno de convergencia, un fondo de preocupaciones comunes aunque estén planteadas desde otro lugar. Me explico mejor. Por un lado, a los folcloristas -como también a los promotores de la Encuesta de 1921- les inquietaba la cuestión de la identidad, más precisamente de la identidad nacional (que algunos creían amenazada) y de la regional o provincial como la expresión más genuina de aquella. Por otro lado, en íntima conexión, existía un interés por atesorar los vestigios, la supervivencia de creencias y de prácticas que parecían fatalmente destinadas a extinguirse por obra de los procesos modernizadores inmigración masiva europea incluida- con todas sus consecuencias no queridas. De algunas de estas supervivencias se reconocía la raíz indígena; de muchas más -vista la relevancia otorgada a los procesos de mestizaje-el origen colonial.

Estas dos cuestiones mantienen su vigencia historiográfica y antropológica, aunque como investigadores ya nos resulten ajenos los afanes conservacionistas del folclore tradicional y sus antiguas intenciones nacionalistas. A mi juicio, los trabajos aquí reunidos especialmente los de Escolar y Villagrán- demuestran hasta qué punto la cuestión identitaria sigue dominando la escena. Y sigue en el centro en la medida en que las manifestaciones folclóricas y también sus corpus textuales han sido objeto de lecturas y de apropiaciones - diferentes de las nuestras- por parte de los sujetos que constituyen nuestro objeto de investigación y que lo resignifican viviéndolo a su manera (volveremos sobre este punto más adelante). 


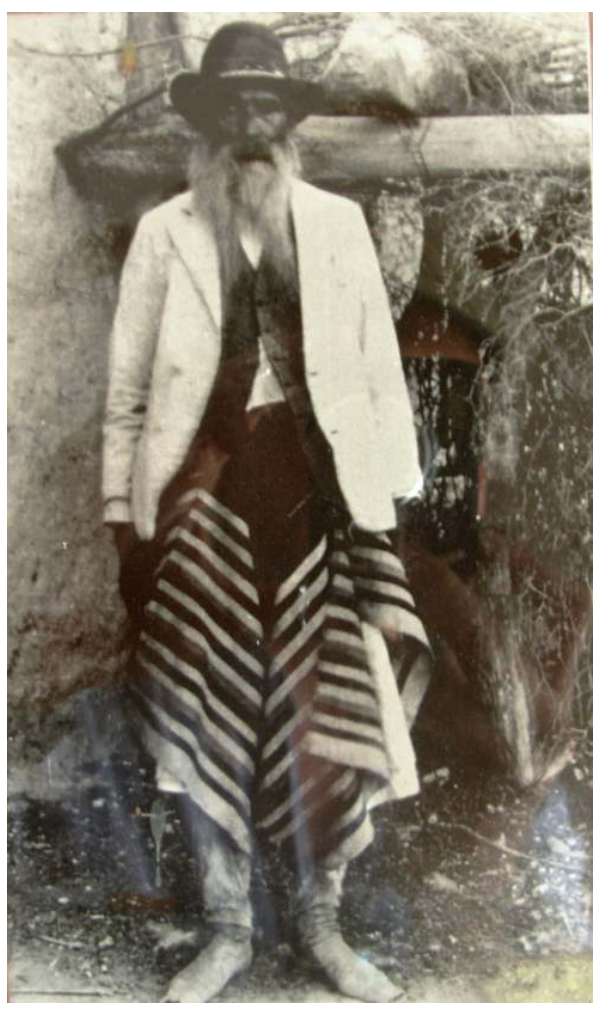

Un tercer problema común a los trabajos en discusión es el del peso relativo del corpus folclórico en la economía de nuestros "archivos" personales y el de los criterios utilizados para relacionar, jerarquizar y dotar de sentido aquella constelación aparentemente caótica de fragmentos de diversa entidad y naturaleza. Entiendo que hay consenso en esta mesa sobre que el corpus folclórico va leído por el investigador dentro de un conjunto más amplio de evidencias vinculadas problemática y contradictoriamente en función del tipo de informaciones aportadas y del método y los presupuestos teóricos de su recolección.

Si coincidimos con los antiguos folcloristas en nuestra preocupación por la identidad, en la búsqueda del pasado en el presente y en la vinculación del corpus folclórico con otros no lo hacemos, generalmente, en la intención y en el modo de producir la información. Una limitación importante fue la que oportunamente enunciara Bernardo Canal Feijóo (1951) cuando, criticando no tan veladamente a sus colegas, proponía reconocer, detrás de la creación anónima, al "pueblo", situado en tiempo y espacio, "pasar de la cosa al hombre". Ricardo Abduca expresa una insatisfacción similar a la de Canal Feijóo cuando lamenta que en la obra de Carrizo se disocien sistemáticamente las manifestaciones folclóricas de los sujetos que las producen: según él, parte del desafío que el corpus folclórico propone al antropólogo se condensa en "restituir el lugar de enunciación y el contexto" de aquel, en "leer antropológicamente" esa peculiar literatura.

En cambio, para Escolar y Villagrán -y también yo lo entiendo así por formación profesional- la gran apuesta es historizar ese corpus -el punto en el que, justamente, Canal Feijóo fracasó aunque le reclamara a los demás que lo hicieran-, una operación compleja en la medida en que el folclore también aspiraba a recoger lo inmemorial, lo que se pierde en la noche de los tiempos (Farberman, 2010). La historia, en efecto, no 
armoniza con el mito, y la folclorización -como bien demuestra Villagrán al referirse a la historiografía de Frías - tiende a deshistorizar.

61 Por lo tanto, encuentro un reclamo común de contextualización del corpus folclórico, contextualización que requiere del cruce, del diálogo con otros corpus que sólo el investigador puede promover sacando a la luz conexiones aparentemente débiles. Creo que de eso hablan Escolar -cuando se refiere a las redes textuales que contribuyen a formar el "archivo huarpe" (o mejor, el "archivo de Escolar sobre los huarpes")- y también Abduca -cuando descubre las conexiones no evidentes (o solo evidentes para el conocedor) entre mujer y pilcha-. Había que vincular diccionarios, literatura gauchesca y datos en apariencia incongruentes, acumulados en sucesivos trabajos de campo para sacar a relucir las relaciones que Abduca fue hilando. Diría, entonces, que los archivos huarpes de Escolar son equiparables a las lecturas dispersas de Ricardo y al conjunto de sus "escuchas etnográficas" recogidas entre la puna jujeña y el Chaco. Y que en el mismo sentido podría leerse el "archivo de los gauchos" de Villagrán, en el que conviven los escritos de Frías con los rituales, las celebraciones y el monumento a Güemes, "legajos virtuales" aptos para abordar la folclorización del pasado salteño y los usos políticos de la historia. Todo ese conjunto heterogéneo - que comporta el involucramiento de diversos actores y productores- es el corpus; la relevancia de lo que el folclore pueda aportarle va ponderada en ese contexto mayor, una construcción del investigador que, como sugiere Escolar, "reclasifica desde la lectura". Las preguntas derivadas del planteo del problema son las que inciden en la consideración de determinados "materiales" dentro del "archivo"; el desafío metodológico que se advierte es cómo organizarlo.

Me parece notable que los tres antropólogos aquí convocados hayan apelado a la producción folclórica clásica para relacionarse con el pasado. Es en este procedimiento inverso al utilizado por los historiadores - que el corpus folclórico se convierte en fuente para la antropología.

\section{La folclorización}

Los textos de Escolar y de Villagrán procuran explicar la folclorización -procesos que tienden a estereotipar, descontextualizar, deshistorizar y esencializar las manifestaciones culturales populares- a partir de ejemplos concretos ${ }^{2}$. El de la construcción de Martín Miguel de Güemes como héroe es paradigmático en este sentido. La historiografía ha demostrado con creces hasta qué punto Güemes (al igual que José Gervasio Artigas) resultaba una figura incómoda, que no terminaba de calificar para prócer (Mata, 2008). Su conflictiva relación con una élite local a la que pertenecía marginalmente, su vinculación con los inquietantes gauchos (los campesinos arrendatarios que obtienen relevantes derechos durante la guerra) y el maltrato del que fue objeto su figura en obras célebres y fundacionales de la historiografía argentina como las Memorias del general Paz o la Historia de Belgrano de Bartolomé Mitre (que recuperaba a Paz para ridiculizar al caudillo salteño) dan cuenta de los esfuerzos necesarios para habilitar el ingreso del salteño al panteón de los héroes de la guerra de independencia. Y a pesar de eso, Bernardo Frías consiguió elevar a Güemes al rango de una figura mítica, portadora de la llave que abría para los salteños el acceso al panteón nacional. Erigida en sentido común, la historiografía tradicional rebatía, a través de Frías, las visiones liberales que, como la de Mitre, evaluaban la gesta independentista desde Buenos Aires y le reservaban a la capital el lugar protagónico. 
64 El trabajo de Villagrán demuestra cómo una de las vías de folclorización del pasado salteño corrió precisamente a través de la deshistorización de Güemes, devenido en personaje extraordinario rodeado de hombres ordinarios. Sería Juan Carlos Dávalos el continuador de la obra de Frías que "mestizó" e hizo de él un producto del paisaje local, un fruto de su tierra. En esta operación, el caudillo mestizo se construyó en un relato historiográfico en el que todos cabían -el mismo Güemes y el pueblo salteño- pero que nada explicaba de la revolución, de la guerra de independencia o del liderazgo político de Güemes. Por fin, este círculo cerró con la monumentalización - que unía caudillo, paisaje y pueblo-y la celebración anual de los actos de homenaje al héroe máximo -que engarza pasado y presente y se proyecta hacia el futuro- ${ }^{3}$.

¿Cuánto de "cultura popular", del objeto privilegiado de estudio del folclore, contienen estos relatos y escenificaciones que integran el corpus de Villagrán? Las conmemoraciones en honor a Güemes organizadas por las asociaciones tradicionalistas como parte de su autocelebración y en beneficio de los políticos locales- son por cierto multitudinarias, con participación de "oligauchos" pero también de peones o campesinos, de gauchos pobres. Estas reuniones variopintas que Villagrán describe me evocaban el diálogo entre un estudiante y su profesor que Julian Barnes (2013) imagina en una novela reciente. Interpelado por el primero, que define provocativamente a la historia como el conjunto de "las mentiras de los vencedores", retruca el segundo: "sí, ya me temía que dijeras eso. Bien, siempre que recuerdes que es también los autoengaños de los derrotados". Aunque la masiva participación popular en la conmemoración güemesiana me suena a "autoengaño de los derrotados", Villagrán nos advierte que tal lectura puede ser superficial. E introduce una cuestión que es clave, que es un tópico y un supuesto del folclore, y que retomaré al final de esta intervención: la alteridad de las lecturas populares de la historia y, en sustancia, de la misma cultura popular.

¿Puede trazarse un paralelo entre las escenificaciones de la gesta de Güemes y las "narrativas de la desaparición huarpe" que Escolar propone? Entiendo que sí. Recordemos que, para Escolar, tales narrativas de la extinción remitían ante todo a "un axioma que tiene más que ver con la autoimagen de clase y étnica de los autores que con un análisis científico de la información disponible", basado en escritos elaborados desde el siglo XIX que tendían a la cancelación de lo indio como parte de la identidad regional. Paradójicamente, se hablaba de los huarpes al mismo tiempo que se negaba su existencia, bien que vaciando a esa entidad de contenido humano, remitiéndola a los vestigios del pasado, sobre todo a los arqueológicos ${ }^{4}$. Sin embargo, el paralelismo entre los dos trabajos podría extenderse aún más cuando se avanza hacia otra cuestión -que, me parece, es la central para Diego y Andrea-cual es la de las reapropiaciones populares - gauchas o huarpes- de esas ideas y valores. Estas reapropiaciones pueden encarnarse en nociones alternativas que niegan la extinción - como en el caso de la identidad huarpe, que desafía a la historia construida diciendo "siempre estuvimos allí", invisibilizados pero en carne y hueso- o que reivindican formas de vida tradicionales - como lo hacen los gauchos de los fortines-. Esta cuestión me sirve de pretexto para regresar al folclore, esta vez como disciplina, y a sus objetos.

\section{Cultura popular y alteridad}

67 Uno de los presupuestos que campea en la literatura folclórica (y no sólo allí) es el de la alteridad de la cultura popular. Ya sea pensada en clave romántica como relicario (de 
producciones no sujetas al cambio), como depósito de las "auténticas tradiciones nacionales" o como concepción alternativa del mundo y de la vida (tal como lo entendía Gramsci), la cultura popular es siempre otra, una otredad subordinada a la cultura hegemónica $u$ oficial ${ }^{5}$.

Esta concepción se presta tanto para la construcción de nociones esencialistas de pueblo (en el sentido de "grupo homogéneo, con hábitos mentales similares, cuyos integrantes son los guardianes de la memoria", Ortiz 1992, p. 26, traducción mía) como para la conceptualización opuesta que ve en lo folclórico un universo sumamente heterogéneo y fragmentado (y por ende incompatible con el "pueblo esencial" de los románticos). Para Gramsci, uno de los autores que más influyó en E. P. Thompson por su propia naturaleza no sistematizada, el folclore era capaz de albergar lo fosilizado y lo innovador; de aquí que, como ha expresado Renato Ortiz, "no se puede discernir en la tradición folclórica un elemento estructural de contestación" sino que su función varía de acuerdo con las condiciones histórico-sociales.

Imagen $N^{\circ} 5$ : Procesión con gauchos huarpes en la Capilla del Rosario. Foto de Diego Escolar

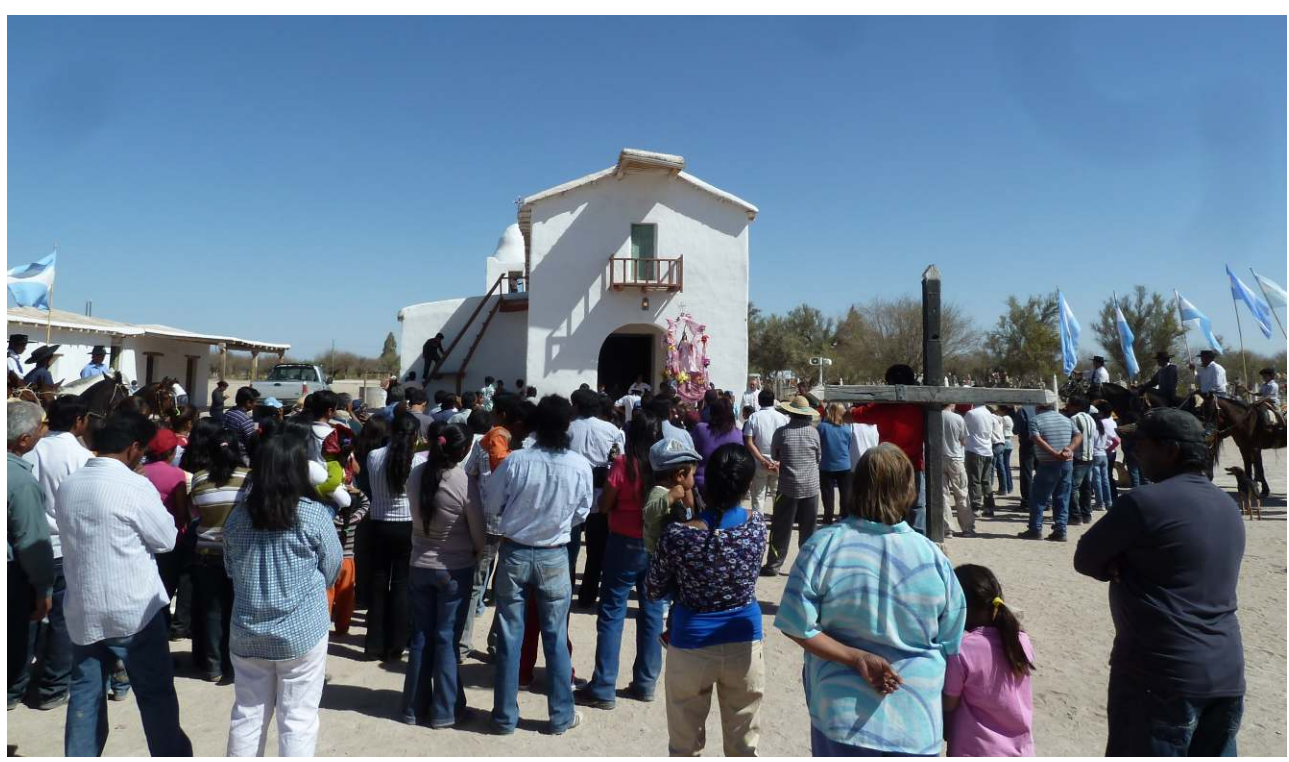

En este punto, regreso sobre una de las ideas del texto de Villagrán, que tanto Abduca como Escolar retoman también en sus réplicas: la de una "folclorización subalterna" y alternativa a la hegemónica. En los fortines salteños, dice Villagrán, lo gaucho expresaría una "teoría nativa que enfatiza su subalternidad en términos de la continuidad ininterrumpida de una antigua forma de vida" en la que el "tesoro" heredado sería fundamentalmente las destrezas camperas. Una identidad, por otra parte, no exenta de contenidos traumáticos, ligados a experiencias de despojo y de las migraciones a la ciudad. Así, en la experiencia histórica compartida y en la disputa por el "ser auténticamente gaucho" se resolvería la alteridad de la cultura folclórica en Salta. Me gusta la idea de Abduca sobre la potencialidad de este entendimiento alternativo del universo gaucho como camino para que las prácticas a él asignadas pierdan el olor a formol y vuelvan a la vida. 


\section{Epílogo: dos palabras sobre el gaucho}

70 La figura del gaucho ha asomado en las tres intervenciones y, siendo la única historiadora del debate, no puedo eludir este tema inicialmente no previsto. Se ha hablado profusamente de literatura y lenguaje gauchescos, de identidades gauchescas (definidas a partir de prácticas, símbolos y de la evocación de un pasado común) y, lo que es muy interesante, pensando sobre todo en los gauchos del interior y no tanto en el clásico arquetipo pampeano.

71 En rigor, las investigaciones históricas de historia social y agraria hace tiempo que han casi desterrado al "gaucho", considerándolo más un estereotipo que una figura de peso en las campañas hoy argentinas. Resultó que los "gauderios" que Concolorcorvo encontrara en el país colonial prácticamente carecían de registro en las fuentes que consideramos más fiables para reconstruir las cartografías sociales del pasado -censos y padrones de población, testamentarias, expedientes judiciales, contabilidades de estancias etc.-: si realmente habían existido, estos personajes eran bastante marginales. Por el contrario, el mundo que se desplegaba a partir de los registros menos impresionistas era predominantemente campesino, de estables familias de labradores que, además, solían desembarcar en las pampas al final de extensos itinerarios migratorios. Un mundo de mestizos con buenas posibilidades de pasar por "españoles" (la mayoría en este contexto de frontera abierta, poco atento a las jerarquías del color), de instalarse autónomamente (en tierras fiscales, ajenas o propias) y de ascender socialmente en el que los squatters eran la excepción y no la regla ${ }^{6}$.

Campesinos y estancieros es el nombre de un libro de Jorge Gelman (1998) sobre la Banda Oriental durante la colonia, y Pastores y labradores de Buenos Aires (1999) se llamó la síntesis de dos décadas de investigaciones publicada por Juan Carlos Garavaglia. Ni terratenientes ni gauchos: para el consenso historiográfico actual, los tipos representativos de las pampas tardo coloniales y de las primeras décadas del siglo XIX eran los pequeños productores (que bien podían incluir a los "estancieros", muy distantes todavía de sus homónimos del período rosista y más aún de los de la Belle Époque de la Argentina), propietarios de cortas cantidades de ganado o cultivadores en tierras a veces propias pero muy a menudo ajenas.

73 Sin embargo, si (con algo de exageración) hablamos del destierro historiográfico del gaucho de la historia agraria y social de la Colonia y la primera mitad del siglo XIX, esto no significó su destierro de otras historiografías más recientes. Por un lado, de la historia intelectual, abocada a la construcción del arquetipo literario a partir de las guerras de independencia y con especial énfasis en el siglo XX, cuando el gaucho elevó su estatura a mito de los orígenes - los mismos Raúl Fradkin (2003) y Jorge Gelman (1995), que tanto aportaron a las discusiones de historia agraria que minimizaban la existencia del gaucho como tipo social, analizaron esta otra dimensión, de indudable impacto en el imaginario de los argentinos-. Por otro lado, en trabajos más recientes que han profundizado en la dimensión política, en la movilización de los pobres rurales, resucitando a los gauchos.

¿En qué momento los paisanos salteños, los arrendatarios y peones de los valles de Lerma y Calchaquí devinieron en gauchos? En un libro reciente, Sara Mata (2008) lo fecha con exactitud en la incorporación de voluntarios a las milicias patriotas (a partir de 1814). La denominación de gaucho "adquirió así una clara connotación militar, estableciéndose quizás con este nombre una velada analogía con los 'gauchos' de la Banda Oriental que al 
mando de José de Artigas luchaban contra los realistas de Montevideo" (Mata, 2008, pp. 74-75). Así, los gauchos adquirían entidad como tales, y con ellos su caudillo, Güemes, hábil para identificarse con ellos. Antes de la guerra contra los realistas, estos gauchos conformaban un grupo tan heterogéneo en sus orígenes, ocupación y calidad socio étnica como el de los paisanos de la campaña de Buenos Aires.

Sin embargo, es en el análisis de Ariel de la Fuente sobre las montoneras riojanas de la segunda mitad del siglo XIX donde los gauchos - que también se forjan como tales en la movilización política - recobran el protagonismo perdido en la historiografía. En rigor, la "cultura política gaucha" es el gran tema de Los hijos de Facundo (2007) y es aprehendida siguiendo dos caminos: el más clásico de la historia social de Los Llanos y Famatina y otro menos convencional que rastrea sus respuestas en los expedientes judiciales y en las fuentes folclóricas (en particular en la Encuesta de 1922). La atención está puesta aquí en la mirada de los paisanos, en las razones que los invitaban a plegarse a sus carismáticos caudillos. Gaucho, así, a la vez que una identidad clasista (pobre rural), deviene una identidad política que, al igual que la misma figura literaria, muere con la consolidación del Estado nacional y la virtual desaparición del federalismo partidario. Por lo tanto, creo no equivocarme (incluso simplificando) al afirmar que en la historiografía de hace tres décadas el gaucho perdió su entidad como tipo social para recobrarla más recientemente como actor en las luchas políticas.

Hecho este rodeo, volvamos al debate, sin pretensiones de cerrarlo. Escolar y Abduca han hecho referencia al papel de lo gaucho como divisoria de aguas en el campo antropológico: lo "indio" tocaba al antropólogo, lo criollo o gaucho, virtualmente desprovisto de etnicidad, al folclorista. Por su parte, Villagrán aspira en su trabajo a comprender la alteridad gauchesca de los fortines, diversa de la que expresa, por ejemplo, la literatura de Dávalos. Me atrae particularmente la sugerencia de Abduca que incluye las tradiciones gauchas en el horizonte más amplio de las "formas de transculturación de lo autóctono y lo foráneo, lo europeo y lo indígena" y que se anima a buscarlas en los estudios lingüísticos.

Al igual que nuestros invitados, me gustaría también a mí concluir con un ejemplo tomado de mis investigaciones personales, abocadas durante varios años al estudio de los santiagueños en tiempos coloniales. Por lo menos desde el siglo XVIII y en coincidencia con el "ascenso del Litoral", hombres y familias migraban desde Santiago del Estero a la campaña de Buenos Aires para participar estacionalmente de las cosechas, conchabarse en las estancias o instalarse como campesinos autónomos en partidos más alejados, iniciando así una práctica pluricentenaria. Algunos de estos migrantes provenían de los pueblos de indios de Santiago, formando parte o no de la "casta tributaria", o sea de quienes tenían derechos legítimos para integrar estas corporaciones coloniales, y sus sonoros apellidos (olvidando a menudo el origen indígena) eran registrados en los padrones porteños. En Santiago estos sujetos hablaban seguramente "la quichua" pero no eran los únicos ni tampoco existía una asociación obligada entre la condición de indio (que va conformándose sobre todo como una categoría jurídica) y la expresión en esa lengua; por cierto, no la habrán olvidado en Buenos Aires.

No dudo, entonces, de que si despojamos al gaucho pampeano de sus atributos clásicos y lo pensamos simplemente como al campesino que la historia agraria redescubrió en las pampas, nos encontraremos con un sinnúmero de indios, mestizos quichua parlantes, incluso negros libres, que refundaban sus identidades en ese nuevo horizonte. Quizás sea justamente ese carácter mestizo (que excede lo biológico, por supuesto) del gaucho y de lo 
gauchesco lo que no ha sido hasta ahora suficientemente subrayado, en especial por los folcloristas.

\section{BIBLIOGRAFÍA}

Barnes, J. (2013). El sentido de un final. Barcelona: Anagrama.

Canal Feijóo, B. (1951). Burla, credo y culpa en la creación anónima. Buenos Aires: Nova (hay reedición de 2010 de la Biblioteca Nacional, con prólogo de Ricardo Abduca).

Chamosa, O. (2012). Breve historia del folclore argentino. 1920-1970: identidad, política y nación. Buenos Aires: Edhasa.

Cortazar, A. R. (1970). Poesía gauchesca. Buenos Aires: Ediciones Culturales Argentinas.

Farberman, J. (2010).Tres miradas sobre paisaje, identidad regional y cultura folclórica en Santiago del Estero. Prismas. Revista de historia intelectual, 14, 71-93. Universidad Nacional de Quilmes.

Fradkin, R. (2003). Centaures de La Pampa. Le gaucho entre l' histoire et le mythe. Annales. Histoire. Sciences Sociales, 58(1), 109-133.

Garavaglia, J. C. (1999). Labradores y pastores de Buenos Aires. Buenos Aires: Editorial de la Flor.

Gelman, J. (1998). Campesinos y estancieros. Una región del Río de la Plata a fines de la época colonial. Buenos Aires: Editorial Los libros del Riel.

Martínez, A.T., Auat, A. y Taboada, C. (2011). Los hermanos Wagner entre ciencia, mito y poesía. Buenos Aires: Universidad Nacional de Quilmes.

Mata, S. (2008). Los gauchos de Güemes. Guerras de independencia y conflicto social. Buenos Aires: Sudamericana.

Mayo, C. et al. (1987). Sobre peones, vagos y malentretenidos. El dilema de la economía rural rioplatense en la época colonial. Anuario IEHS, 2, 25-70.

Ortiz, R. (1980). Gramsci: problemas de cultura popular. A consciencia fragmentada. Ensaios de cultura popular e religiao. Río de Janeiro: Paz e Terra.

Ortiz, R. (1992). Románticos e folcloristas. San Pablo: Olhod'agua.

\section{NOTAS}

1. Todos los términos de esta frase deben leerse con comillas y tomarse con pinzas.

2. Como resultado de este proceso se genera - cito a Andrea Villagrán- "un efecto de naturalización de las prácticas y expresiones culturales, sancionando su carácter espontáneo, heredado, transmitido y legado, su condición de vestigio, huella y supervivencia del pasado".

3. No solamente Güemes ha sido objeto de este tipo de heroización a contrapelo. En términos muy similares -aunque en una obra historiográfica mucho más modesta que la de FríasBernardo Canal Feijóo (1934) conceptualizó a Felipe Ibarra como un producto del paisaje 
santiagueño, mimetizado con la naturaleza. Y al igual que Güemes, también Ibarra fue elevado a héroe por la historiografía revisionista local (aunque sin alcanzar los panteones nacionales).

4. En una operación similar a la que describen Ana Teresa Martínez, Constanza Taboada y Alejandro Auat (2011) para la "civilización chaco-santiagueña" exhumada por los hermanos Wagner. Se trataba de una civilización desaparecida, de la que solo sobrevivía la bella alfarería: sus productores no tenían relación ni parentesco alguno con los indios y criollos del presente.

5. Obviamente, la cultura popular y la docta no eran compartimientos estancos: la circulación y los préstamos entre una y otra cultura son permanentes y los contactos sensibles. Intermediarios culturales (por ejemplo, los sirvientes, las nodrizas) y mecanismos de transmisión (como la literatura popular o el folletín) han conectado siempre las dos culturas.

6. En 1987 se publicó en el Anuario IEHS un debate sobre la mano de obra en los establecimientos productivos de la campaña bonaerense. De los participantes en aquella célebre discusión (Samuel Amaral, Juan Carlos Garavaglia, Jorge Gelman y Carlos Mayo), solo Mayo apostó al gaucho como tipo social representativo de la campaña. Las condiciones de existencia del gaucho se vinculaban en su opinión con el acceso directo a los medios de subsistencia, el mantenimiento de una frontera abierta y de circuitos clandestinos de comercialización, la facilidad de obtener tierras (y con ello de promover una economía agropecuaria paralela a la de los grandes y medianos productores) y la actitud del peón rural ante el trabajo. 